\title{
The land reclamation concept as a key factor in solving the environmental problems of coal mining regions
}

\author{
Tatyana Galanina ${ }^{1 *}$, Tatyana Koroleva ${ }^{1}$, Larisa Zakamskaya $^{1}$, and Inga Tretyakova ${ }^{1}$ \\ ${ }^{1}$ T.F. Gorbachev Kuzbass State Technical University, 28, Vesennyaya, Kemerovo, 650000
}

\begin{abstract}
The impact of coal mining in Kuzbass on the ecosystem of the region is studied in the article. Large-scale mining operations have led to land disturbance over large areas. The coal industry development program, which provides for a significant increase in production, will further aggravate the identified problem. There are a lot of reclamation mechanisms, they must be implemented comprehensively, be high-tech. Large-scale disturbance of land resources, and land retirement, its pollution and littering are the most significant problems requiring a primary solution. The mechanism of state and regional legal regulation of disturbed land reclamation is proposed. Improving the quality of reclamation will be facilitated by the development of a strategy for the environmental remediation, which would be included into the Concept for reclamation of disturbed lands.
\end{abstract}

\section{Introduction}

The Strategy for Socio-Economic Development of the Kemerovo Region until 2035 provides for the further commodity dependence of the economy. The main emphasis is on the fuel and energy, metallurgical and chemical industries. The coal industry development program provides for a further significant increase in coal production.

All this bears evidence of an increase in the anthropogenic load on the ecosystem of the region, the ecological capacity of which is not unlimited.

The Kuznetsk coal basin is the largest not only in terms of coal reserves in Russia, but also in terms of environmental problems associated with their extraction.

Over the past decade, there has been a steady increase in coal production, which reached 250 million tons per year by 2020 .

At the same time, the necessary compensatory environmental measures are significantly behind the production growth rates.

One of the most important negative consequences of mining is vast areas of disturbed land $[1,2,14]$. Currently, according to various sources, about 100 thousand hectares are considered disturbed or partially disturbed in Kuzbass, which led to an acute crisis in land use $[6,7]$.

The maximum contribution to this process is made by open-pit coal mining enterprises $[3,12]$.

\footnotetext{
*Corresponding author: gtv.oe@kuzstu.ru
} 
The planned increase in coal production entails an increase in the area of dumps with hundreds of millions of tons of overburden [15], a reduction in agricultural land, an increase in the area of disturbed lands (sanitary protection zones, haul roads, etc.), social tension $[4,5,6]$. All this leads to the fact that in the Kemerovo region, where at present the anthropogenic impact creates a tense environmental situation, further deterioration with unpredictable consequences is possible.

In general, Kuzbass is characterized by highly-bonded zonal soils; these are mainly chernozem (black soils) and medium humus content soils. However, land resources affected by the activities of coal enterprises are characterized by low agrochemical indicators.

In order to increase soil fertility to the value of soil not subject to anthropogenic impact, a whole range of engineering, mining, ameliorative, biological, sanitary, hygienic and other measures $[7,8]$ called "Reclamation" [16] is required.

This process requires an integrated approach that has not previously been applied due to a lack of understanding of impending environmental risks. The absence or insufficiency of scientifically based knowledge in the field of land reclamation, the priority of economic activity over ecological expediency led to an increase in crisis phenomena in land reclamation, which can only be addressed in a comprehensive manner.

For the period from 2012 to 2018 , less than $20 \%$ of disturbed lands were reclaimed in Kuzbass $[9,10,13]$. There is a deterioration of the human habitat, which is associated with the aggravating environmental situation in an increasingly large territory of the Kuzbass [17]. An increase in coal production in excess of environmental capacity leads to a change in landscapes; associated erosion processes are developing; soil cover is disturbed; pollution of the air, surface and ground water increases; there is a depletion of biological diversity. Environmental pollution and changes in environmental parameters exert slow, accumulative adverse effect on human health, manifested after many decades [11].

The way out of this crisis state, and so far the only and necessary one, should be a way to restore disturbed lands while preserving biological diversity, with a scientifically sound technique, with priority of ecological expediency over economic interest, i.e. reclamation.

\section{Results and discussion}

For Kuzbass, the main problems are:

- commodity dependence;

- the predominance of industries with high anthropogenic load (coal, metallurgical, chemical industries);

- large-scale impact on the main environment media (water, land);

- large areas of land disturbed by coal mining;

- poor quality of environmental remediation.

In the Kemerovo region, the main coal mining enterprises are distributed irregularly and concentrated mainly in the center and in the south of the region. Intensive anthropogenesis areas include Belovsky, Leninsk-Kuznetsky, Guryevsky, Prokopyevsky, Novokuznetsky, Kemerovsky, Yaysky districts.

The current state of these districts of the Kemerovo region can be classified as environmental emergency or environmental disaster zones and indicates the exhaustion of the environmental resources. The situation is aggravated by the fact that $70 \%$ of the population lives in areas of intensive anthropogenesis, which negatively affects, among other things, such an indicator as "the quality of life".

Nevertheless, the Coal Industry Development Program and the Strategy for SocioEconomic Development of the Kemerovo Region until 2035 provide for further growth in coal production. 
In Russia since 2011 to 2018 coal production increased from 336.7 to 439.3 million tons.

The maximum coal production is accounted for by the open pit mining, and more than $60 \%$ is Kuzbass coal.

For the period 2012-2018 8 mines, 8 open-pit mines and 7 concentration plants were commissioned in the Kemerovo region. Moreover, the environmental targets indicated in the Coal Industry Development Program are either on the upper limit or do not meet its requirements (Table 1).

Table 1. Target indicators of the subprogram "Environmental Safety" of the Coal Industry Development Program and values achieved in 2016-2018.

\begin{tabular}{|c|c|c|c|c|}
\hline \multirow[t]{2}{*}{ Target indicator } & \multirow{2}{*}{$\begin{array}{l}\text { According to } \\
\text { the program } \\
\text { for } 2016-2020\end{array}$} & \multicolumn{3}{|c|}{ Actual value } \\
\hline & & 2016 & 2017 & 2018 \\
\hline $\begin{array}{l}\text { Specific discharge of polluted wastewater } \\
\text { into water bodies, } \mathrm{m}^{3} / \mathrm{t} \text { of production }\end{array}$ & $0,7-0,8$ & 0,86 & 0,84 & 0,71 \\
\hline $\begin{array}{l}\text { The share of discharge of polluted } \\
\text { wastewater in the total volume of } \\
\text { discharge, } \%\end{array}$ & $70-60$ & 76,1 & 75,2 & 69,2 \\
\hline Water cycle ratio & $0,8-0,85$ & 0,78 & 0,78 & 0,80 \\
\hline $\begin{array}{l}\text { Specific emission of pollutants into the } \\
\text { atmosphere, } \mathrm{kg} / \mathrm{t} \text { of production }\end{array}$ & $2,4-2,5$ & 2,6 & 2,7 & 2,5 \\
\hline $\begin{array}{l}\text { The share of emission of polluting } \\
\text { substances into the atmosphere in the } \\
\text { total amount of generated pollutants, } \%\end{array}$ & $45-55$ & 58,5 & 58,8 & 69,4 \\
\hline $\begin{array}{l}\text { The ratio of reclaimed land to the annual } \\
\text { land disturbance, } \%\end{array}$ & $65-70$ & 18,7 & 19,0 & 5,5 \\
\hline $\begin{array}{l}\text { The specific volume of waste generation, } \\
t / t \text { of production }\end{array}$ & $5,8-5,9$ & 8,4 & 8,8 & 9,7 \\
\hline $\begin{array}{l}\text { The share of waste disposed in external } \\
\text { dumps, } \% \text { of generated waste }\end{array}$ & $35-40$ & 47,2 & 51,2 & 42,4 \\
\hline $\begin{array}{l}\text { The share of integrated use of production } \\
\text { waste, } \%\end{array}$ & 13 & 52,2 & 54,6 & 53,5 \\
\hline
\end{tabular}

The performance in the field of land conservation is negative. The area of annually disturbed land is growing rapidly. It has grown 2.5 times over the past 6 years. The area of annually reclaimed land remains low, and lags far behind the targets set by the Coal Industry Development Program of Russia until 2030. In 2018, the ratio of reclaimed land to the annual land disturbance amounted to $5.5 \%$, and the lowest ratio for the last year was in Kuzbass $-1.6 \%$.

The data presented show that with an increase in coal production, the area of disturbed land is many times higher than the rate of reclamation. This may be due to at least two reasons:

- land disturbances by newly commissioned enterprises that do not yet have developed lands to reclaim;

- the possibility for nature users to look for loopholes in existing legislation and not to implement these measures or to implement them to a lesser extent.

Considering the second reason, we will try to assess the legal and regulatory framework for land reclamation.

A number of federal acts, such as the Land Code, the Tax Code, the Budget Law, the Code of Administrative Offenses, the Federal Law on Environmental Protection, the 
Federal Law on the Delimitation of State Ownership of Land, the Law on Mineral Resources and others regulate the relationship of nature users with the state in the framework of environment conservation.

Today, land reclamation is carried out in accordance with the Decree of the Government of the Russian Federation dated 10.07.2018 No. 800 "On the implementation of land reclamation and conservation", which defines the regulations for land reclamation and conservation. This decree interprets "land reclamation" as measures to prevent land degradation and (or) restore their fertility by bringing land into a condition suitable for use in accordance with the intended purpose and permitted use, including by eliminating the effects of soil pollution, resoiling and protective forest planting.

The document on the basis of which reclamation is carried out is a reclamation project. A reclamation project is prepared both as part of a project documentation, and as a separate document

In the decree in paragraph 28 , the deadlines for reclamation, which in previous years were a loophole for nature users and reclamation could be postponed for 50-100 years, were finally limited to no more than 15 years, etc.

However, this decree has flaws. So there is no need to agree on technical conditions for the implementation of the reclamation project with the land owner or tenant, if the reclamation is not carried out by the land owner. to him.

That is, the offender himself determines how he will reclaim the land plot not belonging

Of course, the Decree of the Government of the Russian Federation dated 10.07.2018 No. 800 "On the implementation of land reclamation and conservation" is one of the steps to improve the state of land reclamation, but it is clearly insufficient. After all, it is necessary to understand the significance of these activities for mining regions. Kuzbass, where open-pit coal mining is a priority, where most of the population lives in places of intensive mining, where the anthropogenic load on the region goes beyond its ecological capacity, should be able to use other mechanisms.

For further regulation of disturbed land reclamation, the adoption of new regulatory acts is necessary.

It seems appropriate to develop comprehensive measures for regions with intensive land use.

What are the proposed directions for solving the problem of reclamation of disturbed lands?

There are several mechanisms for solving this problem:

1. Development of an integrated mining program.

The Kuznetsk coal basin contains several mineral deposits. An example is the Karakan coal deposit

Coal mining at this deposit is carried out by several coal companies of JSC "MC Kuzbassrazrezugol", Kuzbass Fuel Company, CJSC "Maysky Open Pit", etc., for each of which boundaries of land allotments are established. The boundaries of land allotments significantly exceed the boundaries of mining allotments as additional areas are needed for overburden, haul roads, etc. The area of retired land is significantly increasing. An integrated mining program would allow the most efficient use of land resources. So, for example, overburden of one company could be used to backfill the worked-out space of another coal company; thus, the area allocated for overburden would be cleared, which would reduce the anthropogenic load as a whole.

Unfortunately, to date, the existing environmental legislation does not allow this. 2. Development of mechanisms for the implementation of the Kuzbass environmental management system. 
Currently, the largest coal enterprises have implemented an environmental management system in accordance with the state standard GOST ISO 14000. This is primarily due to the mandatory requirement for the export of coal.

We have already noted the need for integrated mining. A significant mechanism, in this case, could be the introduction of an integrated environmental management system (IEMS). Thus, the introduction of the integrated environmental management system of the Kuznetsk coal basin based on a comprehensive study of the functioning of the fuel and energy industries would not only comprehensively consider the problem of the highest anthropogenic load on the region's ecosystem, but also develop mechanisms for its system and systematic reduction. In this case, it is necessary to develop a system of indicators of the environmental state as the main IEMS tool.

3. Development of the Concept for Reclamation of Disturbed Lands.

The analysis of the regulatory and legal acts of the Kemerovo region on the studied issues showed the lack of an integrated regional approach. Over the past five years, environmental legislation on reclamation of disturbed lands has not been replenished. Several parliamentary hearings; meetings of the Public Chamber of the Kemerovo region, meetings of the Public Council of the Department of Natural Resources and Environment of the Kemerovo region administration were held, however, the proposals made are of a recommendatory nature only and have no legal force. So, for example, in 2018, neither in the laws of the Council of People's Deputies of the Kemerovo region, nor in the decisions and orders of the Governor of the Kemerovo region, nor in the decisions and orders of the Board of the Administration of the Kemerovo region, nor in the orders of the Department of Natural Resources and Environment of the Kemerovo region, there are any materials related to the problem under consideration.

The problem of improving the environmental situation is partly included in Program 2035. However, these measures are clearly not enough.

A concept itself is a strategy, a direction, and therefore it must be inextricably linked with the development of a program. A concept should contain basic principles that would include obligation, timeliness and rigor of high-quality high-tech reclamation.

Private companies are striving to reduce the cost of reclamation. Therefore, it is not surprising that now in Kuzbass coal companies are using the cheapest forms of reclamation, which is a simple way of planting trees and shrubs on the surface of dumps without a scientifically sound and proven technique.

The development and implementation of the Concept for Reclamation of Disturbed Lands could be the starting mechanism for changing the approach to this problem, both by the authorities, and by nature users and regulatory bodies.

For the practical implementation of this Concept, it is necessary to increase the legal independence of regions severely limited by federal legislation. To date, the situation is such that in the absence of federal laws, the constituent entities of the Russian Federations cannot adopt regional laws concerning issues under consideration.

The most important areas of the Concept are:

- development of IEMS - an integrated environmental monitoring system, which allows identifying violations during reclamation, conducting a comprehensive assessment of degradation of land resources, etc. [18, 19, 20];

- development of mechanisms to increase environmental responsibility;

- development of integrated mining mechanisms;

- development of mechanisms for implementing an integrated environmental management system in the region;

- coal mining, providing a reduction in land use intensity.

Environmental-determined development of new coal mining technologies can be carried out by efforts and means of coal companies themselves or by their order. The development 
of holistic technologies for policies aimed at solving environmental problems should be the content of the federal target program for the development of the coal industry of the Russian Federation.

Use $170 \times 250 \mathrm{~mm}$ paper size (W $\times \mathrm{H} \mathrm{mm}$ ) and adjust the margins to those shown in the Table 1 . The final printed area will be $130 \times 210 \mathrm{~mm}$. Do not add any page numbers.

\section{Conclusion}

Reclamation of land disturbed by coal mining should be the most important responsibility of companies engaged in this activity. An unfavorable situation with disturbance of soil cover as a result of coal mining has developed in the region, at which the disturbance rate is many times higher than the reclamation rate. Further growth in coal production aggravates this problem. In addition, the quality of already reclaimed land continues to be very low. This is due to the imperfection of environmental legislation on reclamation and the lack of scientific research. Today, society cannot rely on environmental education and the worldview of nature users, and, therefore, it is necessary to have regulatory and legal leverage to improve the quality of reclamation.

The proposed Concept for Reclamation of Disturbed Lands, which includes several directions, such as developing an integrated mining program, developing an integrated environmental management system for the Kuznetsk coal basin, and introducing an integrated environmental monitoring system will allow for an integrated approach to the development and restoration of natural resources.

\section{References}

1. I. V. Zenkov, Gornyi Zhurnal, 10, 96 (2016)

2. I. V. Zenkov, E. A. Izhmulkina, Y. P. Yuronen, G. I. Yurkovskaya, G. A. Karacheva, Ecology and Industry of Russia, 22:2, 46 (2018)

3. V. G. Mikhailov, N.N. Golofastova, T.V. Galanina, T.G. Koroleva, Ya.S. Mikhailova, IOP Conf. Series: Earth and Environmental Science, 50, 012038 (2017)

4. V. S. Kovalenko, Ugol', 4, 60 (2018)

5. Ju. Janocko, M. Ryzhkova, T. Mamzina, S. Bereznev, E3S Web of Conf., 105, 04030 (2019)

6. O. V. Buresh, A. V. Frolov, Proceedings of the International Conf., 34 (2012)

7. S. V. Bereznev, M. K. Kumaneeva, M. A. Makin, Coal in the 21st Century: Mining, Processing and Safety, 139 (2016)

8. V. Burkov, B. Titorenko, E3S Web of Conf., 91, 08009 (2019)

9. A. V. Novichikhin, V. N. Fryanov, T. V. Petrova, L. D. Pavlova, M. V. Temlyantsev, IOP Conf. Series: Earth and Environmental Science, 84, 012036 (2017)

10. F. Masahisa, P. Krugman, A.J. Venables, The spatial economy: Cities, regions, and international trade (MIT Press, Cambridge, 2001)

11. H. Mehlum, K. Moene, R. Torvik, Economic Journal, 508:116, 1 (2006)

12. D. K. Carter, Remaking Post-Industrial Cities: Lessons from North America and Europe (2016)

13. C. J. Dawkins, Journal of Planning Literature, 2, 131 (2003)

14. V. M. Tumin, A. G. Koryakov, E. P. Nikiforova, World Applied Sciences Journal, 25:6, 645 (2013) 
15. V. G. Mikhailov, T. V. Galanina, Ya. S. Mikhailova, Gornyi Zhurnal, 4, 89 (2019)

16. I. V. Kuznetsova, S. S. Timofeeva, IOP Conf. Series: Earth and Environmental Science, 408, 012075 (2020)

17. T. V. Galanina, V. G. Mikhailov, N. N. Golofastova, T. G. Koroleva, IOP Conf. Series: Earth and Environmental Science, 50, 012037 (2017)

18. I. A. Ageev, V. N. Burkov, V. I. Zinchenko, T. V. Kiseleva, Automation and Remote Control, 66, 995 (2005)

19. S. S. Timofeeva, M. A. Murzin, IOP Conf. Series: Earth and Environmental Science, 408, 012067 (2020)

20. V. P. Avdeev, T. V. Kiseleva, V. N. Burkov, Automation and Remote Control, 62, $1645(2001)$ 